\title{
Localization by monoclonal antibodies of various surface antigens of hamster spermatozoa and the effect of antibody on fertilization in vitro
}

\author{
H. D. M. Moore and T. D. Hartman \\ The Institute of Zoology, Gamete Biology Unit, The Zoological Society of London, Regent's Park, \\ London NWI $4 R Y, U . K$.
}

\begin{abstract}
Summary. To determine the importance during fertilization of various plasma membrane components of the hamster spermatozoon, monoclonal antibodies were generated in the mouse against specific sperm surface antigens. BALB/C mice were immunized with washed hamster spermatozoa from the cauda epididymidis and immune splenocytes fused with myeloma cells $(\mathrm{P} 3 \times 63 \mathrm{Ag} 8)$. The sperm-specific immunoglobulins were detected in hybridoma cultures by a solid-phase assay (ELISA). Five monoclonal antibodies bound specifically to the surface of intact hamster spermatozoa, three immunoglobulins to restricted regions of the head and tail plasmalemma as detected by immunofluorescence. In two cases, the affinity of the membrane antigen was modified during passage through the epididymis. Monoclonal antibodies to the sperm head or to the head and tail inhibited fertilization in vitro by blocking sperm attachment to the zona pellucida and the oolemma.
\end{abstract}

\section{Introduction}

The plasmalemma of the mammalian spermatozoon is regionally differentiated into a number of species-specific surface domains (see Bedford \& Cooper, 1978; Koehler, 1978; Holt, 1982; Moore, 1983). The evidence for this differentiation comes from numerous studies. For instance, probes of cell surface charge such as colloidal iron or cationized ferritin display a discontinuous binding (with a variable density) to different regions of the sperm surface, e.g. acrosome, post-acrosome, midpiece (Cooper \& Bedford, 1971; Yanagimachi, Noda, Fujimoto \& Nicolson, 1972). These patterns reflect the mosaic of membrane carbohydrate moieties that are receptors for lectin markers (Edelman \& Millette, 1971 ; Gordon, Dandekar \& Bartoszewicz, 1974; Millette, 1977), and the internal organization of the plasmalemma as visualized by freeze-fracture studies (see Phillips, 1977; Friend, 1982). A discrete segregation of sperm surface proteins can also be demonstrated by immunological localization of antigen using antiserum to spermatozoa (see O'Rand, 1980; Moore, 1983).

This regionality of the sperm surface is not static, but changes during the development of the spermatozoa (Bedford, Cooper \& Calvin, 1972; Nicolson \& Yanagimachi, 1979; Moore, Hartman \& Holt, 1983). During epididymal transit, for example, there is a modification in the distribution and density of sperm membrane components (see Bedford \& Cooper, 1978), some of which originate from secretions of the epididymal epithelium (Cameo \& Blaquier, 1976; Lea, Petrusz \& French, 1978; Moore, 1980, 1981). Furthermore, it is generally recognized (although as yet unsubstantiated) that, in the female tract, the sperm surface may alter during capacitation (see Moore \& Bedford, 1983). 
A knowledge of the molecular composition of the sperm plasmalemma is essential for an understanding of gamete interactions during development or at fertilization. Currently, two promising approaches are being used to characterize surface determinants. Firstly, intact spermatozoa have been radioiodinated or tritiated to label membrane components which are subsequently analysed by SDS-gel electrophoresis (Olson \& Hamilton, 1978; Nicolson \& Yanagimachi, 1979; Voglmayr, Fairbanks, Jackowitz \& Colella, 1980). Secondly, antibodies against spermatozoa have been employed for immunological investigations (Hjort \& Hansen, 1971; Tung, 1976; Erickson, 1977; Bouteiller, Le Toullet, Rishenzi \& Voisin, 1979; O'Rand \& Romrell, 1980). In the past, however, conventional (polyclonal) antisera have been used although, even with stringent purification protocols, these may not be specific to a single antigen. By contrast, monoclonal antibody production provides highly specific immunoglobulins which usually recognize individual components (Kohler \& Milstein, 1976). Such antibodies have been used to probe the surface of the spermatozoon of several species (Myles, Primakoff \& Bellvé, 1981; Feuchter, Vernon \& Eddy, 1981 ; Schmell, Yuan, Gulyas \& August, 1982). This report describes the preparation of monoclonal antibodies to washed hamster spermatozoa from the cauda epididymidis, the localization and origin of antigen on the sperm surface and the effect of antibody on fertilization in vitro.

\section{Materials and Methods}

\section{Immunization procedures}

Spermatozoa were recovered from the cauda epididymidis of adult hamsters, washed twice in medium BWW + albumin (Biggers, Whitten \& Whittingham, 1971), diluted to $10^{7} / \mathrm{ml}$ and added to an equal volume of Freund's Complete Adjuvant. Female BALB/c mice ( 12 weeks old) were bled from the tail vein for pre-immune serum and then injected with $10^{6}$ spermatozoa in adjuvant $(0 \cdot 2$ $\mathrm{ml}$ ) and again after 2 weeks. After a further 6 weeks, the mice were given a booster injection of $10^{6}$ spermatozoa and 4 days later killed for the fusion (see below). To determine that an adequate immune serum had been raised, mice were bled 4-5 weeks after the initial injection and antibodies in the serum were measured by a solid-phase assay (ELISA, see below).

\section{Cell fusion}

The myeloma cell line P3 $\times 63 \mathrm{Ag} 8$ (obtained from Professor N. A. Mitchison) was grown in Medium RPMI 1640 (Gibco-Europe Ltd) supplemented with $10 \%$ fetal calf serum and $1.0 \mathrm{mm-}$ pyruvate. The procedure for the fusion of myeloma cells (in an active log phase of growth) with immune lymphocytes followed the schedule of Chan \& Mitchison (1982). Briefly, $10^{8}$ spleen cells from 1 or 2 immunized mice and $10^{7}$ myeloma cells were washed in Medium RPMI 1640 and centrifuged at $200 \mathrm{~g}$ for $5 \mathrm{~min}$. The supernatant was carefully removed and $1 \mathrm{ml}$ polyethylene glycol 1500 (BDH Ltd) in Medium RPMI 1640 was added dropwise with continuous stirring at $37^{\circ} \mathrm{C}$. The cells were slowly diluted with medium, centrifuged at $200 \mathrm{~g}$ for $5 \mathrm{~min}$ and resuspended in HAT selection medium (RPMI 1640 supplemented with $15 \%$ fetal calf serum, $1 \times 10^{-4} \mathrm{M}$-hypoxanthine, $4 \times 10^{-7} \mathrm{M}$-aminopterin and $1.6 \times 10^{-5} \mathrm{M}$-thymidine) for pipetting out into 96-well microtest plates (NUNC-Gibco Ltd) at $10^{5}$ cells per well. Hybrid cells were tested for specific antibody activity after 14-21 days of growth.

\section{Solid-phase assay}

Antibodies present in immune serum of hybridoma supernatants were screened by an enzymelinked immunosorbent assay (ELISA, see Voller, Bidwell \& Bartlett, 1979). Hamster spermatozoa from the cauda epididymidis were washed twice in Medium BWW without albumin, resuspended in phosphate-buffered saline and $100 \mu \mathrm{l}$ were pipetted on to flexible polyvinyl chloride 96-well 
microtitre plates (Dynatech Ltd) at a concentration of $10^{5}$ cells per well. Plates were dried overnight at $37^{\circ} \mathrm{C}$ and then submerged in $0.5 \%$ glutaraldehyde for $5 \mathrm{~min}$ followed by 5 washes in $0.15 \mathrm{M}-\mathrm{NaCl}$. Non-specific binding sites were blocked overnight with $1 \%$ bovine serum albumin in phosphatebuffered saline, $\mathrm{pH} 7 \cdot 4$. The plates were then stored at $-80^{\circ} \mathrm{C}$ until their use.

Assays were performed with $100 \mu \mathrm{l}$ immune serum diluted $1: 100$ and then double diluted, or with undiluted hybridoma supernatant. Controls consisted of pre-immune serum $(1: 20-1: 100$ dilution), saline and Medium RPMI and no antigen or second antibody. After incubation for $3 \mathrm{~h}$ at $37^{\circ} \mathrm{C}$ excess antibody was removed by washing with $0 \cdot 15 \mathrm{M}-\mathrm{NaCl}$ three times. The second antibody, rabbit antimouse immunoglobulin (DAKO Ltd), conjugated with horseradish peroxidase (see Voller et al., 1982) was then added $(100 \mu \mathrm{l})$ and the plate incubated at room temperature for a further $2.5 \mathrm{~h}$. Wells were then washed 3 times with $0.15 \mathrm{M}-\mathrm{NaCl}$ before the addition of $200 \mu \mathrm{l}$ of the substrate $o$-phenylenediamine, $1.8 \mathrm{mM}$ in $0.15 \mathrm{M}$-phosphate-citrate buffer, $\mathrm{pH} 5 \cdot 0$. The brown colour product was allowed to develop for 15-30 min before stopping with $50 \mu \mathrm{l} 2 \mathrm{M}-\mathrm{H}_{2} \mathrm{SO}_{4}$. The plate was read at $492 \mathrm{~nm}$ on an automatic plate reader (Titertech Ltd).

\section{Cloning}

Cell lines were cloned twice from specific antibody-secreting hybrid cultures by limited dilution on a mouse peritoneal macrophage feeder layer in 96-well microtitre plates. The concentration of hybrid cells was adjusted to 1 cell per 2 wells. Supernatants were collected 10-20 days after dilution for measurements of antibody titre, or for immunofluorescence and in-vitro fertilization studies. At each stage of culture, positive cell lines were frozen in $10 \%$ dimethyl sulphoxide in Medium RPMI 1640 in liquid nitrogen vapour and then transferred to the liquid phase.

\section{Indirect immunofluorescence}

Hamster spermatozoa recovered from the epididymis were washed by centrifugation in Medium BWW and then used immediately or fixed in $1 \%$ paraformaldehyde in $0.1 \mathrm{M}$-phosphate buffer, $\mathrm{pH} 7 \cdot 4$, for $30 \mathrm{~min}$ followed by two washes in Medium BWW. Spermatozoa, $2 \times 10^{6}$, were incubated with hybridoma supernatant, or serum (pre-immune or immune diluted 1:100 in Medium BWW) for $2 \mathrm{~h}$ at $37^{\circ} \mathrm{C}$. The cells were then washed twice by centrifugation and incubated for $1 \mathrm{~h}$ at $37^{\circ} \mathrm{C}$ with fluorescein-conjugated rabbit antimouse IgG $+\mathbf{M}$ (Miles Lab. Ltd) diluted 1:100. After 3 further washes in Medium BWW, spermatozoa were examined with epifluorescence with a Zeiss Ultraphot microscope.

To assess the binding of monoclonal antibody to somatic cells, brain, liver, kidney and lung tissues from an adult male were excised and gently homogenized. Cells were then fixed and incubated with antibody as described above.

\section{In-vitro fertilization}

The effect of monoclonal antibody on hamster fertilization in vitro was tested using various dilutions of supernatant from cultures of cloned cells.

Hamster spermatozoa from the cauda epididymidis were diluted in Medium BWW containing $20 \%$ heat-treated human serum to a concentration of $5 \times 10^{6} / \mathrm{ml}$ and $0.4 \mathrm{ml}$ drops were incubated under mineral oil for $3 \mathrm{~h}$ at $37^{\circ} \mathrm{C}$ in $5 \% \mathrm{CO}_{2}$ in air. Culture supernatants, some containing spermspecific monoclonal antibody, were added at the beginning or end of the incubation. Female hamsters $(80-120 \mathrm{~g})$ were injected intraperitoneally with 40 i.u. PMSG (Intervet Ltd) on the day of the post-oestrous vaginal discharge and $56 \mathrm{~h}$ later with 40 i.u. hCG (Intervet Ltd). Ova were recovered from each oviduct $15 \mathrm{~h}$ after hCG injection and placed in Medium BWW with $0.4 \%$ albumin and $0 \cdot 1 \%$ hyaluronidase (Sigma) for $3 \mathrm{~min}$. They were then transferred directly to the preincubation spermatozoa or treated with $0.1 \%$ trypsin (Sigma) to dissolve the zona pellucida and 
washed 4 times in fresh medium before being placed in the drops. The oocytes were incubated for a further $3 \mathrm{~h}$, gently washed by repeated aspiration with a Pasteur pipette, fixed in a mixture of ethanol and acetic acid $(3: 1 \mathrm{v} / \mathrm{v})$ for $30 \mathrm{~min}$ and stained with $1 \%$ lacmoid. Eggs were assessed for signs of fertilization (sperm tail and decondensed sperm head in ooplasma), fusion of spermatozoa with the vitellus and sperm attachment to the vitellus or zona pellucida.

\section{Results}

\section{Immunization and detection of antibodies}

A preliminary investigation demonstrated that a short course of two i.p. injections of hamster spermatozoa into BALB/c mice provoked a good immune response in most individuals within 4 weeks. A booster injection 3-4 days before the fusion procedure is essential to prime mouse splenocytes and ensure that there is a sufficient number of antibody-producing cells. A crucial aspect of the production of monoclonal antibody is the detection of specific immunoglobulin in serum or in culture supernatant. The enzyme-linked immunosorbent assay (ELISA) provided a rapid, sensitive and safe method of measuring antibody binding to fixed hamster spermatozoa. With a 3-h incubation of diluted mouse serum it was possible to detect levels of anti-sperm immunoglobulin significantly higher than in pre-immune control serum at 1:8000 to $1: 16000$ dilution (Text-fig. 1). Intra- and inter-assay variations were $<5 \%$. Hybridoma cells were designated as secreting anti-sperm immunoglobulin if undiluted supernatant from the cultures gave an absorbance reading 4 times the level of control supernatant from the parent myeloma cells (absorbance $=0.08$ ). After subsequent cloning, cultures were reassayed for confirmation of antibody production. Nine stable hybridoma cell lines secreting monoclonal antibody directed against hamster spermatozoa were prepared in two fusion experiments.

\section{Immunofluorescent localization of antigen}

A priority in this investigation was the development of monoclonal antibodies against the hamster sperm surface. Since the ELISA involved drying spermatozoa and thus exposing some of their intracellular contents it was necessary to determine the precise localization of antigen by

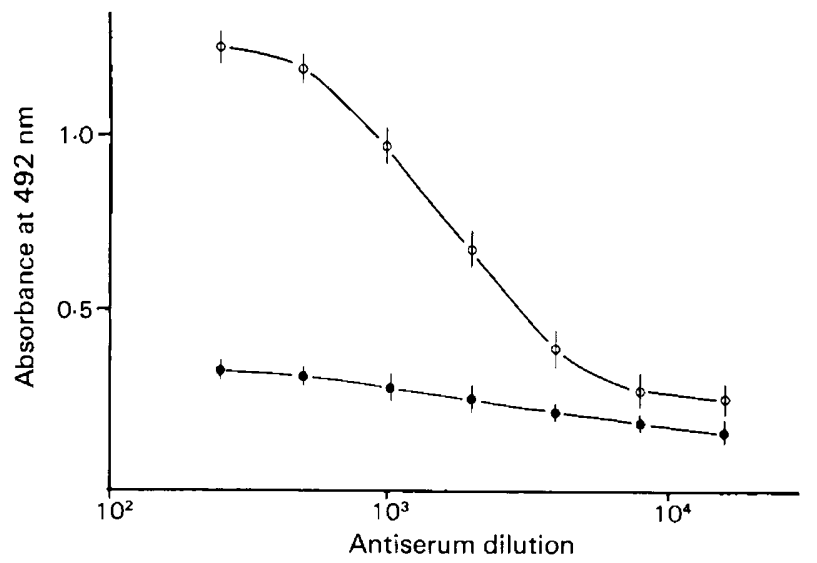

Text-fig. 1. Enzyme-linked immunosorbent assay titration curves for immune serum $(\mathrm{O}-\mathrm{O})$ obtained from a mouse injected twice with washed epididymal hamster spermatozoa $\left(10^{6}\right)$. Pre-immune serum $(-1)$ ); bars represent standard error. See text for procedure. 

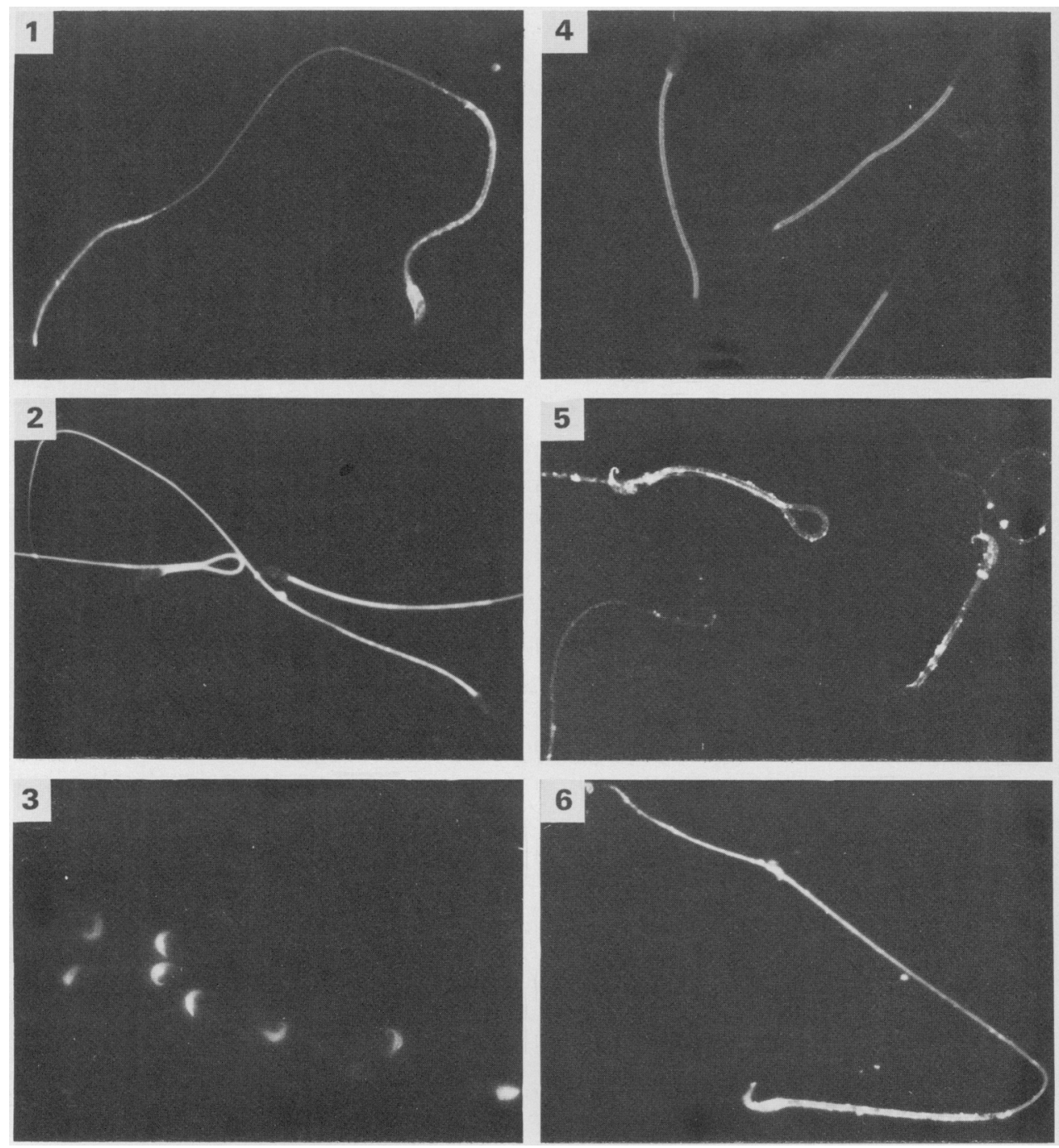

Fig. 1. Immunofluorescent localization of antibody binding. A spermatozoon incubated with supernatant from Clone 1.0. Monoclonal antibody is bound to the entire sperm surface. $\times 470$.

Fig. 2. Spermatozoa incubated with supernatant from Clone 5.8. Monoclonal antibody is bound to the sperm tail but not the head. $\times 390$.

Fig. 3. Spermatozoa incubated with supernatant from Clone 3.10. Monoclonal antibody is bound only to the sperm head (acrosomal and post acrosomal region). $\times 350$.

Fig. 4. Spermatozoa incubated with supernatant from Clone 9.0. Monoclonal antibody is bound to the midpiece. $\times 470$.

Fig. 5. Spermatozoa incubated with supernatant from Clone 2.0. Monoclonal antibody is bound to the sperm surface of the head and tail and gives a characteristic spotty appearance. $\times 390$.

Fig. 6. A spermatozoon incubated with immune serum from a mouse injected with washed hamster spermatozoa. Antibody is bound over the entire sperm surface. $\times 470$. 
indirect immunofluorescence using fresh or fixed epididymal spermatozoa. Of the 7 monoclonal antibodies detected by solid-phase assay, 5 bound to the surface of intact spermatozoa from the cauda epididymidis. The pattern of binding for each antibody is shown in P1. 1, Figs 1-6. In the absence of first antibody, or in the presence of pre-immune serum or supernatants of non-immunoglobulin-secreting cell lines, no fluorescence was observed. After disruption of spermatozoa (by homogenization), immunofluorescence of cellular debris was noted with the remaining two monoclonal antibodies which had initially failed to bind to intact spermatozoa. These immunoglobulins have not been investigated further.

Three monoclonal antibodies attached to specific regions of the sperm plasmalemma: HM 3.10 bound to the sperm head, HM 5.8 to the entire tail and HM 9.0 to the midpiece. By contrast, HM 1.0 bound to the head and tail, giving an immunofluorescent pattern similar to that produced by the immune serum positive control. HM 2.0 evoked a characteristic and reproducible staining on the head and tail of spermatozoa (fixed and unfixed) which was distinct from the pattern produced by HM 1.0.

Immunofluorescent localization of antigen was also investigated with washed spermatozoa from different regions of the excurrent duct (Table 1). The affinity of HM 3.10 (as assessed by the degree of fluorescence and the proportion of spermatozoa displaying fluorescence) to spermatozoa recovered from the cauda epididymidis was significantly greater than to cells from the testis or proximal regions of the epididymis. In addition, a small difference in the ability of HM 5.8 to bind to the surface of spermatozoa from different regions of the epididymis was observed (Table 1).

Table 1. Immunofluorescent localization of antigen on spermatozoa recovered from various regions of the hamster epididymis $(n=4)$

\begin{tabular}{lcccc}
\hline Clone & $\begin{array}{c}\text { Initial } \\
\text { segment }\end{array}$ & Caput & Corpus & Cauda \\
\hline 1.0 & \pm & + & + & + \\
2.0 & + & + & + & + \\
3.10 & \pm & + & +++ & +++ \\
5.8 & - & + & ++ & + \\
9.0 & + & + & + & + \\
\hline
\end{tabular}

$(-)$ negative, $( \pm)$ weak fluorescence on a proportion of cells; $(+)$ weak, $(++)$ medium and $(+++)$ strong fluorescence on all spermatozoa.

The specificity of monoclonal antibody for spermatozoa was tested by immunofluorescent studies with somatic cell preparations. Antigen was visualized on spermatozoa and in some cases on testicular sperm cells also, but not on heart, liver, kidney, lung or brain tissue.

\section{In-vitro fertilization}

The effect of monoclonal antibody (in culture supernatant) or serum at various dilutions on fertilization in vitro with intact or zona-free hamster eggs is shown in Text-fig. 2. During incubation in vitro, hamster spermatozoa spontaneously agglutinated but subsequently dispersed and became freely motile as capacitation proceeded. At high concentrations of hybridoma supernatant $\mathbf{H M}$ $3.10,2.0$ and 5.8 (i.e. $1: 40-1: 100$ dilution), the dispersion of agglutinated spermatozoa after incubation for 2-3 $\mathrm{h}$ was inhibited, although the motility pattern of spermatozoa with the remaining immunoglobulins was not significantly different from that of control samples. The latter consisted of spermatozoa incubated with the supernatant of hybridomas not secreting sperm antibody. At dilutions of supernatant greater than 1:100, sperm motility and agglutination patterns were unaffected with all the monoclonal antibodies, and spermatozoa incubated for 3-4 h 

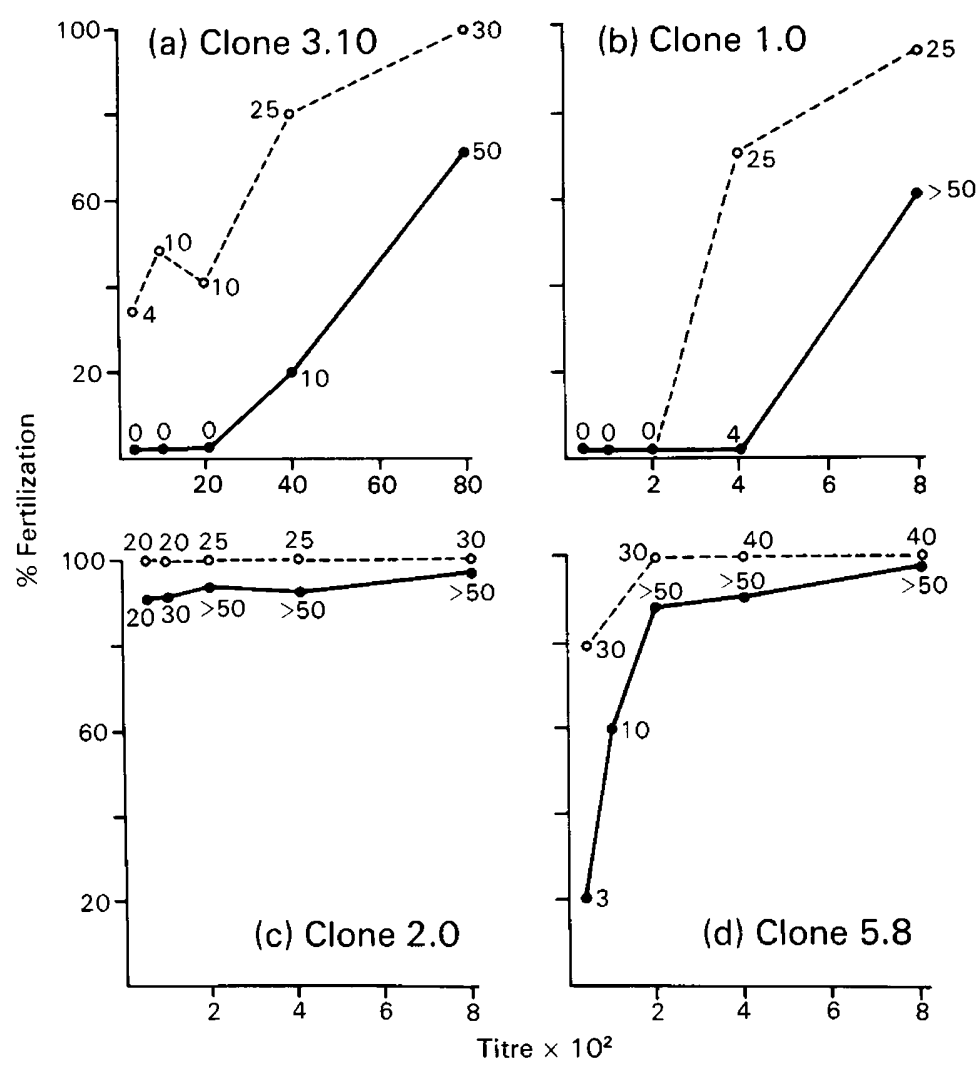

Text-fig. 2. Titration curves of the effect of culture supernatant from cloned hybridomas on fertilization in vitro of intact $(-C)$ and zona-free $\left(\mathrm{O}_{----} \mathrm{O}\right)$ hamster oocytes. Value beside circle denotes mean number of spermatozoa bound to egg. Each measurement was based on 10-15 oocytes. (a) Supernatant from Clone 3.10 (against head antigen). At 1:2000 dilution fertilization of intact oocytes was completely blocked; $50 \%$ of zona-free oocytes were penetrated by spermatozoa. (b) Supernatant from Clone 1.0 (against head and tail antigen). At 1:400 dilution, intact oocytes remained unfertilized although $70 \%$ of zona-free oocytes were penetrated. (c) Supernatant from Clone 2.0 (against head and tail antigen) failed to inhibit fertilization of intact or zona-free oocytes. Similar results were found with supernatant from 9.0 (against midpiece antigen). (d) Supernatant from Clone 5.8 (against tail antigen). Some inhibition of fertilization with intact oocytes occurred at 1:40-1:100 dilution. Most zona-free oocytes were penetrated.

displayed activated motility. The ability of spermatozoa incubated with hybridoma supernatant or serum to bind to the zona pellucida or the egg plasmalemma is illustrated in Text-fig. 2 .

Supernatant from Clone 3.10 was extremely effective at inhibiting fertilization. Dilution of $1: 2000$ completely blocked the binding of spermatozoa to the zona pellucida and reduced the number of spermatozoa bound to the vitellus of zona-free oocytes. A similar titration curve was observed with supernatant from Clone 1.0 although total inhibition of fertilization only occurred at dilutions between $1: 200-1: 400$. In contrast, supernatants of Clones 2.0 and 9.0 failed to inhibit fertilization of oocytes even at high concentrations $(1: 40)$. The supernatant of Clone 5.8 reduced the fertilization rate at dilutions of $1: 40$ to $1: 100$ but agglutination of spermatozoa in the culture also occurred at these titres.

The site of action of antibody on fertilization in vitro was investigated by preincubating intact and zona-free hamster ova with hybridoma supernatant or antiserum. These eggs were then rinsed 
3 times in medium and incubated with spermatozoa. In each case, the fertilization rate was not significantly different from that of controls.

\section{Discussion}

In this investigation, monoclonal antibodies have been raised against the surface of hamster spermatozoa by hybridizing mouse myeloma cells with immune splenocytes (Kohler \& Milstein, 1976). The highly specific immunoglobulins produced by this method recognize antigens restricted to different regions of the sperm surface, confirming the results of many studies over the past decade that the plasmalemma of mammalian spermatozoa is differentiated into distinct surface domains (see Bedford \& Cooper, 1978; Holt, 1982). The present study complements similar investigations generating monoclonal antibodies to mouse (Bechtol, Brown \& Kennett, 1979; Feuchter et al., 1981 ; Schmell et al., 1982; Gaunt, 1982), guinea-pig (Myles et al., 1981) and human (Sokoloski, Bechtol \& Wolf, 1982) spermatozoa.

A crucial aspect in the production of monoclonal antibodies is the development of a rapid and sensitive detection of specific immunoglobulin. The enzyme-linked immunosorbent assay reported here is based on protocols for mainly soluble antigens; however, hamster spermatozoa absorbed on microtitre plates were resistant to removal after extensive washing and gave highly reproducible results. The assay compares well with other solid-phase methods using labelled protein A (Schmell et al., 1982) or radioautographic techniques (Feuchter et al., 1981). Overnight incubation with primary immunoglobulin increases sensitivity substantially and this approach is currently being utilized to detect clones secreting sperm-specific antibody at early stages of culture.

In view of the studies with specific polyclonal antibodies to sperm surface components (Hjort \& Hansen, 1971; Tung, 1976), the unique binding patterns of each monoclonal antibody were not surprising. The cloning protocols used here do, however, ensure a degree of specificity which is difficult to achieve by other methods. Most of the hybrid cell cultures isolated in this study produced immunoglobulin directed to tail rather than to specific head antigens. This may be due to the relatively long tail of the hamster spermatozoon providing more antigen and hence a greater immune response.

With respect to the fluorescent localization of sperm antigen with monoclonal antibody, although it was usual for the binding of antibody to be restricted to a region of sperm surface, at least one monoclonal antibody (HM 1.0) displayed an even affinity to all of the sperm plasmalemma in a manner similar to that produced by polyvalent antiserum, thus indicating the presence of common membrane components throughout the plasmalemma. Secondly, the fluorescence obtained with HM 2.0 was of a patchy or spotty nature, possibly reflecting an antigen that is mobile laterally within the membrane, as suspected for sperm membrane particles visualized by freeze-fracture (Friend, 1982). Finally, the initial appearance in the reproductive tract of antigen on spermatozoa also varied. In particular, the antigen on the sperm head to which HM 3.10 was generated apparently increased during epididymal transit such that the intensity of fluorescent staining and the proportion of spermatozoa displaying fluorescence was greater on those cells from the distal epididymis than on those from the caput epididymidis or testis. This alteration in the ability of monoclonal antibody to bind to spermatozoa in the epididymis has been observed by others (Feuchter et al., 1981). Certainly, the appearance of sperm antigen during maturation can be accounted for by specific protein, secreted by the epididymal epithelium in the distal caput and proximal corpus region, which attaches to spermatozoa during epididymal transit (Lea et al., 1978; Moore, 1980, 1981). Another possible explanation is that an integral membrane antigen may become unmasked or altered, for instance glycolysated (Hamilton \& Gould, 1981), and thereby increase its affinity for antibody. De-novo synthesis of proteins by testicular or epididymal spermatozoa has not been detected (Moore, 1971) but components could also be inserted into the plasmalemma by fusion of cytoplasmic membrane (see Holt, 1982). 
The functional importance of the antigens localized with monoclonal antibody was assessed using in-vitro fertilization assays. In high concentrations antibodies most probably inhibited fertilization non-specifically by irreversibly agglutinating spermatozoa. The supernatants from two clones had no effect on sperm motility, however, and were ineffective in preventing fertilization on sperm fusion with zona-free hamster eggs. In contrast, monoclonal antibodies HM 3.10 and 1.0 significantly inhibited fertilization in vitro at dilutions which did not alter sperm motility. Indeed, spermatozoa exhibited the activated movements associated with the completion of capacitation (Katz \& Yanagimachi, 1980). Since sperm binding to the zona pellucida was reduced in the presence of these immunoglobulins, they may act by blocking sperm receptors for the zona pellucida, although inhibition of sperm fusion at the vitelline surface was also evident because spermatozoa failed to penetrate zona-free oocytes. Whether the block to fertilization by these monoclonal antibodies reflects a highly specific masking of receptors or a steric hindrance phenomenon due to the large size of $\operatorname{IgG}$ and $\operatorname{IgM}$ molecules is at present unclear. Nevertheless, studies of rabbit, hamster and guinea-pig spermatozoa, in which Fab fragments prepared against antigens still remain capable of inhibiting fertilization in vivo and in vitro (Tzartos, 1979; Moore, 1981; Huang, Tung \& Yanagimachi, 1981), favour the former mechanism.

This study was supported by grants from the Ford Foundation and the M.R.C. We thank Professor N. A. Mitchison and Dr Lin Chan, Department of Zoology, University College London, for helpful advice and the gift of myeloma cells; Terry Dennett for photography; and Julie Clayton, a summer student supported by a grant from the Nuffield Foundation.

\section{References}

Bechtol, K.B., Brown, S.C. \& Kennett, R.H. (1979) Recognition of differentiation antigens of spermatogenesis in the mouse by using antibodies from spleen cell-myeloma hybrids after syngeneic immunization. Proc, natn. Acad. Sci. U.S.A. 76, 363-367.

Bedford, J.M. \& Cooper, G.W. (1978) Membrane fusion events in the fertilization of vertebrate eggs. In Cell Surface Reviews: Membrane Fusion, Vol. V, pp. 65125. Eds G. Poste \& G. L. Nicolson. Elsevier/North Holland, Amsterdam.

Bedford, J.M., Cooper, G.W. \& Calvin, H.I. (1972) Postmeiotic changes in the nucleus and membranes of mammalian spermatozoa. In The Genetics of the Spermatozoon, pp. 69-83. Eds R. A. Beatty \& S. Gluecksohn-W aelsch. R. A. Beatty \& S. GluecksohnWaelsch, Edinburgh.

Biggers, J.D., Whitten, W.K. \& Whittingham, D.G. (1971) The culture of mouse embryos in vitro. In Methods in Mammalian Embryology, pp. 86-116. Ed. J. C. Daniel, Jr. Freeman, San Francisco.

Bouteiller, P.P., Le Toullet, F., Rishenzi, S. \& Voisin, G.A. (1979) Ultrastructural localization of guinea-pig spermatozoal autoantigens on germinal cells by immunoperoxidase techniques. J. Histochem. Cytochem. 27, 857-866.

Cameo, M.S. \& Blaquier, J.A. (1976) Androgen-controlled specific proteins in rat epididymis. J. Endocr. 69, 47-55.

Chan, W.L. \& Mitchison, N.A. (1982) The use of somatic cell hybrids for the production of monospecific viral antibodies. In New Developments in Practical Vir- ology, pp. 125-141. Ed. C. R. Howard. A. R. Liss, New York.

Cooper, G.W. \& Bedford, J.M. (1971) Acquisition of surface charge by the plasma membrane of mammalian spermatozoa during epididymal maturation. Anat. Rec. 169, 300-301.

Edelman, G.M. \& Millette, C.F. (1971) Molecular probes of spermatozoan structures. Proc. natn. Acad. Sci. U.S.A. 68, 2436-2440.

Erickson, R.P. (1977) Differentiation and other alloantigens of spermatozoa. In Immunobiology of Gametes, pp. 85-107. Eds M. Edidin \& M. H. Johnson. Cambridge University Press.

Feuchter, F.A., Vernon, R.B. \& Eddy, E.M. (1981) Analysis of the sperm surface with monoclonal antibodies. Topographically restricted antigens appearing in the epididymis. Biol. Reprod. 24, 10991110 .

Friend, D.S. (1982) Plasma membrane diversity in a highly polarized cell. J. Cell Biol. 93, 243-249.

Gaunt, S.J. (1982) A 28K Dalton cell surface autoantigen of spermatogenesis. Characterization using monoclonal antibody. Devl Biol. 89, 92-100.

Gordon, M., Dandekar, P.V. \& Bartoszewicz, W. (1974) Ultrastructural localization of surface receptors for concanavalin $A$ on the rabbit spermatozoa. $J$. Reprod. Fert. 36, 211-214.

Hamilton, D.W. \& Gould, R.P. (1981) Preliminary observations on enzymatic galactosylation of glycoproteins on the surface of rat caput epididymal spermatozoa. Int. J. Androl., Suppl. 5, 73-80. 
Hjort, T. \& Hansen, K.B. (1971) Immunofluorescent studies of human spermatozoa. I. The detection of different spermatozoal antibodies and their occurrence in normal and infertile women. Clin. exp. Immunol. 8, 9-23.

Holt, W.V. (1982) Functional development of the mammalian sperm plasma membrane. Oxford Rev. Reprod. Biol. 4, 195-240.

Huang, T.T.F., Tung, K.S. \& Yanagimachi, R. (1981) Autoantibodies from vasectomised guinea pigs inhibit fertilization in vitro. Science, N.Y. 213, $1267-$ 1269.

Katz, D.F. \& Yanagimachi, R. (1980) Movement characteristics of hamster spermatozoa within the oviduct. Biol. Reprod. 22, 759-764.

Koehler, J.K. (1978) The mammalian sperm surface. Studies with specific labelling techniques. Int. Rev. Cytol. 54, 73-107.

Kohler, G. \& Milstein, C. (1976) Derivation of specific antibody producing tissue. Eur. J. Immunol. 6, 511519.

Lea, O.A., Petrusz, P. \& French, F.S. (1978) Purification and localization of acidic epididymal glycoprotein (AEG): a sperm coating protein secreted by the rat epididymis. Int. J. Androl., Suppl. 2, 592-605.

Millette, C.F. (1977) Distribution and mobility of lectin binding sites on mammalian spermatozoa. In Immunobiology of Gametes, pp. 51-71. Eds M. Edidin \& M. H. Johnson. Cambridge University Press.

Moore, G.P.M. (1971) DNA-dependent RNA synthesis in fixed cells during spermatogenesis in the mouse. Expl Cell. Res. 68, 462-467.

Moore, H.D.M. (1980) Localization of specific glycoproteins secreted by the rabbit and hamster epididymis. Biol. Reprod. 22, 705-718.

Moore, H.D.M. (1981) Glycoprotein secretions of the epididymis in the rabbit and hamster: localization on epididymal spermatozoa and the effect of specific antibodies on fertilization in vivo. J. exp. Zool. 215, $77-85$.

Moore, H.D.M. (1983) Physiological and in vitro models of sperm maturation. In Serono Clinical Colloguia on Reproduction, Vol. 4, pp. 9-38. Eds P. G. Crosignani \& B. L. Rubin. Academic Press, London.

Moore, H.D.M. \& Bedford, J.M. (1983) The interaction of mammalian gametes in the female. In Mechanism and Control of Animal Fertilization, pp. 453-497. Ed. J. F. Hartmann. Academic Press, New York.

Moore, H.D.M., Hartman, T.D. \& Holt, W.V. (1983) Sperm maturation in the common marmoset. J. Anat. (in press).

Myles, D.G., Primakoff, P. \& Bellvé, A.R. (1981) Surface domains of the guinea-pig sperm defined by monoclonal antibodies. Cell 23, 433-439.

Nicolson, G.L. \& Yanagimachi, R. (1979) Cell surface changes associated with the epididymal maturation of mammalian spermatozoa. In The Spermatozoon, pp. 187-194. Eds D. W. Fawcett \& J. M. Bedford. Urban and Schwarzenburg, Baltimore.

Olson, S.E. \& Hamilton, D.W. (1978) Characterization of surface glycoproteins of rat spermatozoa. Biol. Reprod. 19, 26-35.

O'Rand, M.G. (1980) Antigens of spermatozoa and their environment. In Immunological Aspects of Infertility and Fertility Regulation, pp. 155-171. Eds D. S. Dhindsa \& G. F. B. Schumacher. Elsevier/North Holland, Amsterdam.

O'Rand, M.G. \& Romrell, L.J. (1980) Appearance of regional surface autoantigens during spermatogenesis. Comparisons of antitestis and anti-sperm autoantisera. Devl Biol. 75, 431-441.

Phillips, D.M. (1977) Surface of the equatorial segment of the mammalian acrosome. Biol. Reprod. 16, 128137.

Schmell, E.D., Yuan, L.C., Gulyas, B.J. \& August, J.T. (1982) Identification of mammalian surface antigens. I. Production of monoclonal anti-mouse sperm antibodies. Fert. Steril. 37, 249-257.

Sokoloski, J.E., Bechtol, K.B. \& Wolf, D.P. (1982) Mapping the human sperm surface; molecular characterization of an individual antigen. Biol. Reprod. 26, Suppl. 1, 87A, Abstr.

Tung, K.S.K. (1976) Human sperm antigens and antisperm antibodies. III. Studies on acrosomal antigens. Clin. exp. Immunol. 24, 292-299.

Tzartos, S.J. (1979) Inhibition of in-vitro fertilization of intact and denuded hamster eggs by univalent antisperm antibodies. J. Reprod. Fert. 55, 447-455.

Voglmayr, J.K., Fairbanks, G., Jackowitz, M.A. \& Colella, J.R. (1980) Post-testicular developmental changes in the ram sperm cell surface and their relationship to luminal fluid proteins of the reproductive tract. Biol. Reprod. 22, 655-667.

Voller, A., Bidwell, D.E. \& Bartlett, A. (1979) The Enzyme Linked Immunosorbent Assay (ELISA), pp. 1-125. Dynatech Europe, Guernsey.

Voller, A., Bidwell, D.E. \& Bartlett, A. (1982) ELISA techniques in virology. In New Developments in Practical Virology, pp. 59-79. Ed. C. R. Howard. A. R. Liss, New York.

Yanagimachi, R., Noda, Y.F., Fujimoto, M. \& Nicolson, G.L. (1972) The distribution of negative surface charge on mammalian spermatozoa. Am. J. Anat. 135, 497-520.

Received 9 May 1983 